\title{
Pengembangan Buku Ajar Keterampilan Menulis Bahasa Arab Berbasis Kearifan Lokal Sebagai Penunjang Kreativitas Mahasiswa
}

\author{
Zaim Elmubarok, Darul Qutni, Muchlisin Nawawi \\ Universitas Negeri Semarang \\ Corresponding author: darulqutni@mail.unnes.ac.id
}

\begin{abstract}
Basic Arabic writing skills are included in the competency-based curriculum and conservation of the Arabic Education Study Program. Learning basic Arabic writing skills is provided through the taroqib wa takhawiljumal course. Learning basic Arabic writing skills, based on local wisdom, introducing our nation's culture and increasing students' creativity in writing Arabic. The research subjects were students who took taroqib wa takhawiljumal totaling 30 people, data collection methods used in this study included (1) potential and problems, (2) data collection, (3) product design, (4) design validation, (5) design revision. Learning basic Arabic writing skills based on local wisdom introduces students to their culture, creative in writing Arabic, and encourages to better written language.
\end{abstract}

Keterampilan menulis bahasa Arab tingkat dasar masuk ke dalam kurikulum berbasis kompetensi dan konservasi Program Studi Pendidikan Bahasa Arab. Pembelajaran ketrampilan menulis bahasa Arab tingkat dasar diberikan melalui mata kuliah taroqib wa takhawiljumal. Pembelajaran ketrampilan menulis bahas Arab tingkat dasar, berbasis kearifan lokal mengenalkan budaya bangsa kita dan meningkatkan daya kreativitas mahasiswa dalam menulis bahasa Arab, Subjek penelitiannya adalah mahasiswa yang mengambil mata kuliah taroqib wa takhawiljumal berjumlah 30 orang, metode pengumpulan data yang digunakan pada penelitian ini meliputi (1) potensi dan masalah, (2) pengumpulan data, (3) desain produk, (4) validasi desain, (5) revisi desain. Pembelajaran

ISSN 2622-6146 (e) 2622-6138 (p)

(C) 2019 Alsina : Journal of Arabic Studies

http://journal.walisongo.ac.id/index.php/alsina 
keterampilan menulis bahasa Arab tingkat dasar berbasis kearifan lokal ini mengenalkan mahasiswa terhadap budaya, kreatif dalam menulis bahasa arab, dan terdorong untuk berbahasa tulis yang lebih baik.

Keywords: kearifan lokal; kreativitas; menulis Bahasa Arab.

\section{Pendahuluan}

Menurut Hasan (1979) Dalam bahasa Arab, terdapat ungkapan-ungkapan (lughat al-Qur'an) 'gaya Al-Qur'an', (lughatu al-uyun) bahasa mata (lughat al-thuyur) bahasa burung dan lain sebagainya. Dalam pembelajaran bahasa Arab, ada tiga kompetensi yang harus dimiliki yaitu: kompetensi kebahasaan (al-kifayah al-lughowiyah), kompetensi komunikasi (al-kifayah al-ittishaliyah), dan kompetensi peradaban (al-kifayah al-tsaqafiyah). Yang dimaksud dengan kompetensi kebahasaan adalah penguasaan guru atas aturanaturan suara (fonetik) bahasa Arab, mengetahui sistem pembentukan kata (morfologi), tata bahasa atau qawaid (sintaksis), dan juga banyak menguasai kosakata-kosakata bahasa Arab dan cara penggunaannya dalam kalimat. Sedangkan yang dimaksud dengan kompetensi komunikasi adalah kemampuan dosen dalam berbahasa Arab atau berkomunikasi kepadama hasiswa dengan menggunakan bahasa Arab yang mudah dipahami oleh mahasiswa, dan juga kemampuan dosen dalam menyampaikan atau mengkomunikasikan empat kemahiran bahasa Arab tersebut kepada mahasiswa dengan metode dan strategi pembelajaran yang komunikatif, mudah diterima oleh mahasiswa, dan menyenangkan. Kemudian, kompetensi peradaban adalah kemampuan dosen dalam memahami nilai-nilai budaya atau peradaban yang terkandung dalam bahasa Arab, karena bahasa Arab bagaimanapun juga mengandung muatan nilainilai budaya Arab, yang bisa berupa adat, kebiasaan, dan pemikiran-pemikiran orang Ada dua aspek Kemahiran 
menulis, tetapi dalam hubungan yang berbeda. Pertama, kemahiran membentuk huruf dan menguasai ejaan; kedua kemahiran melahirkan pikiran dan perasaan dengan tulisan.

\section{Kemahiran Membentuk Huruf}

Inti dari kemahiran menulis dalam pengajaran bahasa terletak pada aspek kedua. Dalam kenyataan kita lihat, banyak orang yang dapat menulis Arab dengan amat baik, tetapi tidak paham makna kalimat yang ditulisnya, apalagi melahirkan maksud dan pikirannya sendiri dengan bahasa Arab. Sebaliknya tidak sedikit sarjana bahasa Arab yang tulisannya seperti "cakar ayam"

Mengemukakan kenyataan ini, tidak berarti menafikan pentingnya kemahiran menulis dalam aspek pertama, karena kemahiran dalam aspek pertama mendasari kemahiran dalam aspek kedua. Oleh karena itu, walaupun kemampuan menulis alfabet Arab telah dilatih sejak tingkat permulaan, tetapi dalam tingkat-tingkat selanjutnya pembinaan harus tetap dilakukan, paling tidak sebagai variasi kegiatan.

Latihan tersebut ditekankan kepada kemampuan menulis huruf Arab dalam berbagai posisinya benar, terutama yang menyangkut penulisan hamzah dan alif layyinah.

Segi artistiknya (khat) barangkali tidak teramat penting, meskipun tidak boleh diabaikan, kecuali bagi calon guru bahasa Arab dan agama yang memang dituntut oleh profesinya untuk dapat menulis Arab tidak saja benar tetapi juga baik.

Secara umum pengajaran menulis bertujuan agar siswa dapat berkomunikasi secara tertulis dalam bahasa Arab.

\section{Kemahiran mengungkapkan dengan tulisan}

Aspek ini seperti ditegaskan di muka merupakan inti dari kemahiran menulis. Latihan menulis ini pada prinsipnya diberikan setelah latihan menyimak, berbicara dan membaca. 
Ini tidak berarti bahwa latihan menulis ini hanya diberikan setelah siswa memiliki ketiga kemahiran tersebut di atas. Latihan menulis dapat diberikan pada jam yang sama dengan latihan kemahiran yang lain; sudah tentu dengan memperhatikan tahap-tahap latihan sesuai dengan tingkat kemampuan siswa. Nilai tersebut yang akan menjadi landasan hubungan mereka atau menjadi acuan tingkah laku mereka.

Dalam pembelajaran ketrampilan menulis bahasa Arab tingkat dasar, tidak hanya mahasiswa diajarkan kebudayaan bangsa Arab, tapi juga harus dikenalkan tentang kearifan bangsa Indonesia. Bukan berarti belajar bahasa asing hanya belajar kebahasaan bangsa asing, tetapi lebih dari itu melalui keterampilan menulis bahasa arab tingkat dasar bisa mengenalkan kearifan lokal bangsa kita, karena dengan mengenalkan budaya atau kearifan bangsa kita mahasiswa menjadi berpikir kreatif dan inovatif, maka membutuhkan buku ajar menulis bahasa arab tingkat dasar yang berbasis kearifan lokal.

Buku ajar sering kali disebut dengan buku teks atau buku pelajaran (Direktorat Pendidikan Menengah Umum 2004:3) memaparkan bahwa buku teks atau buku pelajaran adalah sekumpulan tulisan yang dibuat secara sistematis berisi tentang suatu materi pelajaran tertentu yang disiapkan oleh pengarangnya dengan menggunakan acuan kurikulum yang berlaku.

Buku ajar disusun dengan tujuan sebagai berikut: Pertama, Menyediakan bahan ajar yang sesuai dengan tuntutan kurikulum dengan mempertimbangkan kebutuhan peserta didik, yakni bahan ajar yang sesuai dengan karakteristik dan seting atau lingkungan sosial peserta didik. Kedua, membantu peserta didik dalam memperoleh alternatif bahan ajar di samping buku-buku teks yang terkadang sulit diperoleh. Ketiga, Memudahkan pengajar dalam melaksanakan pembelajaran. 


\section{Metode}

Penelitian ini menggunakan jenis penelitian dan pengembangan (research and development). Penelitian dan pengembangan adalah metode penelitian yang digunakan untuk menghasilkan produk tertentu, dan menguji keefektifan produk tersebut (Sugiyono 2012:407). Sedangkan menurut Sukmadinata (2012:164) penelitian dan pengembangan adalah suatu proses atau langkah-langkah untuk mengembangkan suatu produk baru atau menyempurnakan produk yang telah ada yang dapat dipertanggungjawabkan

Prosedur penelitian yang dirancang oleh Borg dan Gall (2003), disederhanakan oleh Sugiyono (2010:409) menjadi: (1) potensi dan masalah, (2) pengumpulan data, (3) desain produk, (4) validasi desain, (5) revisi desain, (6) uji coba produk, (7) revisi produk, (8) uji coba pemakaian, (9) revisi produk, dan (10) produk massal. Penelitian ini terdiri dari dua tahap yakni tahap pertama dan tahap kedua. Tahap pertama dilakukan pada tahun pertama, yakni mulai dari langkah pertama sampai langkah kelima, sedangkan tahap kedua dilakukan pada tahun kedua yakni mulai dari langkah keenam sampai langkah kesembilan. Langkah penelitian kesepuluh (produk massal) tidak dilaksanakan dalam penelitian ini.

\section{Pembahasan}

\section{Konsep Kearifan Lokal}

Kearifan lokal menurut UU No. 32/2009 tentang perlindungan dan lingkungan hidup Bab I Pasal 1 butir 30 adalah "nilai-nilai luhur yang berlaku dalam tata kehidupan masyarakat untuk antara lain melindungi dan mengelola lingkungan hidup secara lestari."

Ridwan (2007 : 2) dalam penelitiannya menyimpulkan, "kearifan lokal atau sering disebut local wisdom dapat dipahami sebagai usaha manusia dengan menggunakan akal 
budinya (kognisi) untuk bertindak dan bersikap terhadap sesuatu, objek, atau peristiwa yang terjadi dalam ruang tertentu."

Pengertian tersebut, disusun secara etimologi, di mana wisdom dipahami sebagai kemampuan seseorang dalam menggunakan akal pikirannya dalam bertindak atau bersikap sebagai hasil penilaian terhadap sesuatu, objek, atau peristiwa yang terjadi. Sebagai sebuah istilah wisdom sering diartikan sebagai "kearifan/kebijaksanaan". Local secara spesifik menunjuk pada ruang interaksi terbatas dengan sistem nilai yang terbatas pula. Sebagai ruang interaksi yang sudah didesain sedemikian rupa yang di dalamnya melibatkan suatu pola-pola hubungan antara manusia dengan manusia atau manusia dengan lingkungan fisiknya. Pola interaksi yang sudah terdesain disebut setting. Setting adalah sebuah ruang interaksi tempat seseorang dapat menyusun hubunganhubungan face to face dalam lingkungannya. Sebuah setting kehidupan yang sudah terbentuk secara langsung akan memproduksi nilai-nilai. Nilai-nilai tersebut yang akan menjadi landasan hubungan mereka atau menjadi acuan tingkah laku mereka.

Keraf (2010:369) dalam penelitiannya menyimpulkan sebagai berikut, "yang dimaksud dengan kearifan tradisional di sini adalah semua bentuk pengetahuan, keyakinan, pemahaman atau wawasan serta adat kebiasaan atau etika yang menuntun perilaku manusia dalam kehidupan di dalam komunitas ekologis. Jadi kearifan lokal ini bukan hanya menyangkut pengetahuan dan pemahaman masyarakat adat tentang manusia dan bagaimana relasi yang baik di antara manusia, melainkan juga menyangkut pengetahuan, pemahaman dan adat kebiasaan tentang manusia, alam, dan bagaimana relasi di antara semua penghuni komunitas ekologi ini harus dibangun. Seluruh kearifan tradisional ini dihayati, dipraktikkan, diajarkan dan diwariskan dari satu generasi ke 
generasi lain yang sekaligus membentuk pola perilaku manusia sehari-hari, baik terhadap sesama manusia maupun terhadap alam dan Yang Gaib."

Berdasarkan pengertian di atas, hal tersebut menunjukkan beberapa hal:

Pertama, kearifan lokal adalah milik komunitas. Demikian pula, yang dikenal sebagai pengetahuan tentang manusia, alam dan relasi dalam alam juga milik komunitas. Tidak ada pengetahuan atau kearifan tradisional yang bersifat individual.

Kedua, Kearifan lokal yang juga berarti pengetahuan tradisional, lebih bersifat praktis, atau "pengetahuan bagaimana". Pengetahuan dan kearifan masyarakat adat adalah pengetahuan bagaimana hidup secara baik dalam komunitas ekologis, sehingga menyangkut bagaimana berhubungan secara baik dengan semua isi alam. Pengetahuan ini juga mencakup bagaimana memperlakukan setiap bagian kehidupan dalam alam sedemikian rupa, baik untuk mempertahankan kehidupan masing-masing spesies maupun untuk mempertahankan seluruh kehidupan di alam itu sendiri. Itu sebabnya, selalu ada berbagai aturan yang sebagian besar dalam bentuk larangan atau tabu tentang bagaimana menjalankan aktivitas kehidupan tertentu di alam ini.

Ketiga, kearifan lokal bersifat holistik, karena menyangkut pengetahuan dan pemahaman tentang seluruh kehidupan dengan segala relasinya di alam semesta. Alam adalah jaring kehidupan yang lebih luas dari sekedar jumlah keseluruhan bagian yang terpisah satu sama lain. Alam adalah rangkaian relasi yang terkait satu sama lain, sehingga pemahaman dan pengetahuan tentang alam harus merupakan suatu pengetahuan menyeluruh.

Keempat, berdasarkan kearifan lokal dengan ciri seperti itu, masyarakat adat juga memahami semua aktivitasnya 
sebagai aktivitas moral. Kegiatan bertani, berburu dan menangkap ikan bukanlah sekedar aktivitas ilmiah berupa penerapan pengetahuan ilmiah tentang dan sesuai dengan alam, yang dituntun oleh prinsip-prinsip dan pemahaman ilmiah yang rasional. Aktivitas tersebut adalah aktivitas moral yang dituntun dan didasarkan pada prinsip atau tabu-tabu moral yang bersumber dari kearifan tradisional.

Kelima, berbeda dengan pengetahuan barat yang mengklaim dirinya sebagai universal, kearifan lokal yang bersifat tradisional, karena terkait dengan tempat yang partikular dan konkret. Kearifan dan pengetahuan tradisional selalu menyangkut pribadi manusia yang partikular (komunitas masyarakat adat itu sendiri), alam (di sekitar tempat tinggalnya) dan relasinya dengan alam itu. Tetapi karena manusia dan alam bersifat universal, kearifan dan pengetahuan tradisional dengan tidak direkayasa pun menjadi universal pada dirinya sendiri. Kendati tidak memiliki rumusan universal sebagaimana dikenal dalam ilmu pengetahuan modern, kearifan tradisional ternyata ditemukan di semua masyarakat adat atau suku asli di seluruh dunia, dengan substansi yang sama, baik dalam dimensi teknis maupun dalam dimensi moralnya.

Sedangkan menurut Teezzi (dalam Ridwan, 2007:3) mengatakan bahwa "akhir dari sedimentasi kearifan lokal ini akan mewujud menjadi tradisi atau agama”. Dalam masyarakat kita, kearifan-kearifan lokal dapat ditemui dalam nyanyian, pepatah, sasanti, petuah, semboyan, dan kitab-kitab kuno yang melekat dalam perilaku sehari-hari. Kearifan lokal biasanya tercermin dalam kebiasaan-kebiasaan hidup masyarakat yang telah berlangsung lama. Keberlangsungan kearifan lokal akan tercermin dalam nilai-nilai yang berlaku dalam kelompok masyarakat tertentu. Nilai-nilai itu menjadi pegangan kelompok masyarakat tertentu yang biasanya akan menjadi 
bagian hidup tak terpisahkan yang dapat diamati melalui sikap dan perilaku mereka sehari-hari.

Proses sedimentasi ini membutuhkan waktu yang sangat panjang, dari satu generasi ke generasi tersebut. Teezzi mengatakan bahwa "kemunculan kearifan lokal dalam masyarakat merupakan hasil dari proses trial and error dari berbagai macam pengetahuan empiris maupun non-empiris atau yang estetik maupun intuitif" (Ridwan, 2007:3).

Ardhana (dalam Apriyanto, 2008:4) menjelaskan bahwa: menurut perspektif kultural, kearifan lokal adalah nilai yang diciptakan, dikembangkan dan dipertahankan oleh masyarakat yang menjadi pedoman hidup mereka. Termasuk berbagai mekanisme dan cara untuk bersikap, bertingkah laku dan bertindak yang dituangkan sebagai suatu tatanan sosial.

Di dalam pernyataan tersebut terlihat bahwa terdapat lima dimensi kultural tentang kearifan lokal, yaitu (1) pengetahuan lokal, yaitu informasi dan data tentang karakter keunikan lokal serta pengetahuan dan pengalaman masyarakat untuk menghadapi masalah serta solusinya. Pengetahuan lokal penting untuk diketahui sebagai dimensi kearifan lokal sehingga diketahui derajat keunikan pengetahuan yang dikuasai oleh masyarakat setempat untuk menghasilkan inisiasi lokal; (2) Budaya lokal, yaitu yang berkaitan dengan unsur-unsur kebudayaan yang telah terpola sebagai tradisi lokal, yang meliputi sistem nilai, bahasa, tradisi, teknologi; (3) Keterampilan lokal, yaitu keahlian dan kemampuan masyarakat setempat untuk menerapkan dan memanfaatkan pengetahuan yang dimiliki; (4) Sumber lokal, yaitu sumber yang dimiliki masyarakat untuk memenuhi kebutuhan dasarnya dan melaksanakan fungsi-fungsi utamanya; dan (5) proses sosial lokal, berkaitan dengan bagaimana suatu masyarakat dalam menjalankan fungsifungsinya, sistem tindakan sosial yang dilakukan, tata hubungan sosial serta kontrol sosial yang ada. 
Kearifan lokal dapat didefinisikan sebagai suatu kekayaan budaya lokal yang mengandung kebijakan hidup: pandangan hidup (way of life) yang mengakomodasi kebijakan (wisdom) dan kearifan hidup. Di Indonesia - yang kita kenal sebagai Nusantara- kearifan lokal itu tidak hanya berlaku secara lokal pada budaya atau etnik tertentu, tetapi dapat dikatakan bersifat lintas budaya atau lintas etnik sehingga membentuk nilai budaya yang bersifat nasional. Sebagai contoh, hampir di setiap budaya lokal di Nusantara dikenal kearifan lokal yang mengajarkan gotong royong, toleransi, etos kerja, dan seterusnya. Pada umumnya etika dan nilai moral yang terkandung dalam kearifan lokal diajarkan turun-temurun, diwariskan dari generasi ke generasi melalui sastra lisan (antara lain dalam bentuk pepatah dan peribahasa, folklore), dan manuskrip.

Walaupun ada upaya pewarisan kearifan lokal dari generasi ke generasi, tidak ada jaminan bahwa kearifan lokal akan tetap kukuh menghadapi globalisasi yang menawarkan gaya hidup yang makin pragmatis dan konsumtif. Secara faktual dapat kita saksikan bagaimana kearifan lokal yang syarat kebijakan dan filosofi hidup nyaris tidak terimplementasikan dalam praktis hidup yang makan pragmatis.

\section{Prototipe Buku Ajar Menulis Bahasa Arab Tingkat Dasar Berbasis Kearifan Lokal}

Berdasarkan hasil analisis angket kebutuhan, penyusunan buku ajar menulis bahasa arab tingkat dasar berbasis kearifan lokal disusun sesuai dengan acuan dan pertimbangan hasil analisis kebutuhan tersebut. Hasil analisis angket kebutuhan dijadikan sebagai acuan dalam penyusunan buku ajar menulis bahasa arab tingkat dasar berbasis kearifan lokal

Validasi Ahli Buku Ajar Menulis Bahasa Arab Tingkat Dasar Berbasis Kearifan Lokal 
Pengembangan Buku Ajar Keterampilan Menulis Bahasa Arab ...

Setelah menyusun buku ajar menulis bahasa arab tingkat dasar berbasis kearifan lokal sesuai gambar dari tema dan judul yang menggambarkan kearifan lokal.

Kategori Penilaian Prototipe Buku ajar menulis bahasa arab tingkat dasar berbasis kearifan lokal.

\begin{tabular}{clc}
\hline Skor & \multicolumn{1}{c}{ Kategori } & $\begin{array}{c}\text { Rentang } \\
\text { Nilai }\end{array}$ \\
\hline 4 & Sangat layak atau sangat sesuai & $86-100$ \\
\hline 3 & Layak atau sesuai & $71-85$ \\
\hline 2 & Tidak layak atau tidak sesuai & $56-70$ \\
\hline 1 & $\begin{array}{l}\text { Sangat tidak layak atau sangat tidak } \\
\text { sesuai }\end{array}$ & $41-55$ \\
\hline
\end{tabular}

Aspek Penilaian Desain Produk Oleh Ahli Buku ajar menulis bahasa arab tingkat dasar berbasis kearifan lokal.

Penilaian buku ajar menulis bahasa arab tingkat dasar berbasis kearifan lokal. salah satunya meliputi kelayakan isi, apakah isi yang dipaparkan di dalamnya sesuai dan akurat, serta terpenuhnya bagian-bagian yang harus ada dalam sebuah buku ajar dan sebagainya.

\begin{tabular}{|c|c|c|c|c|}
\hline $\begin{array}{c}\text { Aspek } \\
\text { Penilaian }\end{array}$ & Kriteria & Nilai & $\begin{array}{c}\text { Rentangan } \\
\text { Nilai }\end{array}$ & Skor \\
\hline $\begin{array}{l}\text { Aspek } \\
\text { Kelayakan } \\
\text { isi }\end{array}$ & $\begin{array}{l}\text { Sangat } \\
\text { Baik }\end{array}$ & 89 & $84-100$ & 4 \\
\hline $\begin{array}{l}\text { Aspek } \\
\text { Kelayakan } \\
\text { Penyajian }\end{array}$ & $\begin{array}{l}\text { Sangat } \\
\text { Baik }\end{array}$ & 90 & $84-100$ & 4 \\
\hline $\begin{array}{l}\text { Aspek } \\
\text { Bahasa } \\
\end{array}$ & $\begin{array}{l}\text { Sangat } \\
\text { Baik }\end{array}$ & 87 & $84-100$ & 4 \\
\hline $\begin{array}{l}\text { Aspek } \\
\text { Kegrafikan }\end{array}$ & $\begin{array}{l}\text { Sangat } \\
\text { Baik }\end{array}$ & 90 & 84-100 & 4 \\
\hline
\end{tabular}




\section{Kesimpulan}

Analisis kebutuhan Buku ajar menulis bahasa arab tingkat dasar berbasis kearifan lokal.

1. Mahasiswa merasa senang belajar ketrampilan menulis bahasa Arab tingkat dasar berbasis kearifan lokal, mereka merespon sangat senang (75 \%) dan senang (25\%)

2. Tingkat kesulitan mahasiswa dalam memahami materi ketrampilan menulis bahasa Arab tingkat dasar berbasis kearifan lokal , mahasiswa merespon sangat sulit (73\%) dan sulit (27\%)

3. Dibutuhkan buku ajar dalam pembelajaran ketrampilan menulis bahasa Arab tingkat dasar berbasis kearifan lokal direspon oleh mahasiswa, sangat butuh (93\%) dan butuh $(7 \%)$

4. Buku ajar yang berupa diktat dalam pembelajaran ketrampilan menulis bahasa arab berbasis kearifan lokal mahasiswa merespon, sangat butuh (95\%) dan butuh $(5 \%)$

5. Bentuk buku ajar yang dibutuh kan dalam ketrampilan menulis bahasa arab tingkat dasar berbasis kearifan lokal, direspon mahasiswa, buku (95\%) dan kliping (5\%)

6. Materi sebagai bahan ajar ketrampilan menulis bahasa arab tingkat dasar berbasis kearifan lokal direspon mahasiswa, budaya arab (25\%) dan budaya lokal (75\%)

7. Buku ajar yang berbasis kearifan lokal akan memudah kan belajar ketrampilan menulis bahasa arab tingkat dasar berbasis kearifan lokal, direspon mahasiswa ,mudah (75\%) dan tidak mudah (25\%)

8. Materi kearifan lokal buku ajar cocok untuk ketrampilan menulis bahasa arab tingkat dasar berbasis kearifan lokal, direspon mahasiswa, sangat cocok (80\%) dan cocok (20\%) 
9. Materi kearifan lokal mana yang cocok untuk ketrampilan menulis bahasa arab tingkat dasar berbasis kearifan lokal, direspon mahasiswa budaya Jawa modern (75\%) dan budaya Jawa tradisional (25\%)

10. Saran yang terbaik untuk buku ajar ketrampilan menulis bahasa arab tingkat dasar berbasis kearifan lokal direspon oleh mahasiswa, cetak (75\%) dan soft copy (25\%)

\section{Daftar Pustaka}

Arikunto, Suharsimi. 2006. Prosedur Penelitian, Suatu Pendekatan Praktek. Jakarta: PT. Rineka Cipta.

2010. Prosedur Penelitian Suatu Pendekatan Praktik. Jakarta: PT. Rineka Cipta.

Dahar, R.W. 1988. Teori-Teori Belajar. Jakarta: Depdikbud

Echols, John M. \& Shadily, Hasan. 1995. Kamus InggrisIndonesia: An English-Indonesian Dictionary. Jakarta: Penerbit Gramedia.

Eggen, P.D \& Kauchak, P.P.. 1996. Strategies for Teacher: Teaching Content and Thingking Skill. Boston: Alyn \& Bacon.

Hanafiah, Nanang dan Cucu Suhana. 2012. Konsep Strategi Pembelajaran. Bandung: PT Refika Aditama.

Isjoni, H. 2011. Pembelajaran Kooperatif Meningkatkan Kecerdasan KomunikasiAntar Peserta Didik. Yogyakarta: Pustaka Pelajar.

Moleong, J. Lexy. 1995. Metodologi Penelitian Kualitatif. Bandung: Penerbit Remaja Rosdakarya.

Nasution, S. 2003. Asas-asas Kurikulum. Jakarta : Bumi Aksara. Nazir.2005.Metode Penelitian. Bogor: Ghalia Indonesia. 
Zaim Elmubarok, Darul Qutni, Muchlisin Nawawi

Nur, Muhammad. 2005. Pembelajaran Kooperatif. Departemen Pendidikan Nasional Direktorat Pendidikan Dasar dan Menengah Lembaga Penjamin Mutu Jawa Timur.

Nurhadi, dan Senduk, A. G. 2009.Pembelajaran Kontekstual. Surabaya: PT. JePe Press Media Utama.

Rusman. 2012. Model-Model Pembelajaran Mengembangkan Profesionalisme Guru. Jakarta: PT Raja Grafindo Persada.

Sukmadinata, Nana Syaodih. 2007. Metode Penelitian Pendidikan. Bandung: PT. Remaja Rosdakarya Offset 